\title{
Effect of abattoir waste water on metabolic and antioxidant profiles of cowpea seedlings grown in crude oil contaminated soil
}

\author{
F. I. Achuba ${ }^{1} \cdot$ M. O. Ja-anni ${ }^{2}$
}

Received: 26 July 2017 / Accepted: 19 December 2017 / Published online: 10 January 2018

(c) The Author(s) 2018. This article is an open access publication

\begin{abstract}
Purpose The pollution of agricultural land by crude oil is a wide spread phenomenon in petroleum producing countries of the world. Therefore, there is the need to find effective and eco-friendly means of mitigating the toxic effect of crude oil on crop plants.

Methods Green house experiment was conducted with cowpea seeds planted in polybags containing crude oil contaminated soil and similar concentrations treated with known amount of abattoir wastewater. The effect of abattoir wastewater (AWW) treatment of the crude oil contaminated soil on the metabolic and antioxidant properties of the leaves of cowpea seedlings was investigated. The concentrations of total sugar, total protein, total amino acid and $\beta$-carotene, chlorophyll, starch metabolizing enzymes as well as oxidative stress markers, lipid peroxidation, catalase, xanthine oxidase, aldehyde oxidase and superoxide dismutase were determined using standard methods.

Results Treatment of the crude oil contaminated soil with AWW resulted in decreases in total sugar, total protein and total amino acid as well as increase in the activities of both $\alpha$-amylase and starch phosphorylase and total chlorophyll and $\beta$-carotene levels compared with those in crude oil alone treated groups. Treatment of the crude oil contaminated soil with AWW also significantly decreased lipid peroxidation and Cu/ZnSOD, but increased MnSOD, catalase, xanthine oxidase and aldehyde oxidase activities.

Conclusion These observations suggest that abattoir wastewater has the ability to remediate the adverse effects of crude oil polluted soil on cowpea seedlings. Therefore, abattoir wastewater should be harnessed and used in treating crude oil polluted farmland so as to reduce its toxicity on crop plants.
\end{abstract}

Keywords Abattoir $\cdot$ Cowpea $\cdot$ Crude oil $\cdot$ Metabolism $\cdot$ Antioxidants

\section{Introduction}

Soil pollution by petroleum hydrocarbon is common in crude oil producing areas (Sivaraj et al. 2014), which results in changes in soil properties such as water and oxygen shortage, soil enzymes activities as well as deficiency in nitrogen and phosphorous (Wyszkowski et al. 2004; Wyszkowski and Wyszkowska 2005; Achuba 2006; Wyszkowski and

F. I. Achuba

achubabch@yaoo.com

M. O. Ja-anni

jaannimary@gmail.com

1 Department of Biochemistry, Delta State University, PMB 1, Abraka, Nigeria

2 Department of Biochemistry, Delta State University, Abraka, Nigeria
Ziolkowska 2008; Achuba 2014; Achuba and Okoh 2014; Otitoju et al. 2017).

Plants growing in soils contaminated with crude oil and its refined products have been reported to exhibit several anomalies in their metabolism and growth indices. The notable symptoms observed in plants growing on soil treated with petroleum hydrocarbons include decrease in chlorophyll content (Achuba 2006; Peretiemo-Clarke and Achuba 2007; Al-Hawas et al. 2012), decrease in the activities of starch metabolizing enzymes (Achuba 2006), increase in total carbohydrates, total proteins and amino acids (Peretiemo- Clarke and Achuba 2007; Al-Hawas et al. 2012) and in the activities of peroxidase, ascorbate peroxidase and superoxide dismutase, and inhibition of catalase activity (Al-Hawas et al. 2012).

Bioremediation is one of the best methods used to restore contaminated soil (Romantschuk et al. 2000). Crude oil 
contaminated soils are modifiable by bioremediation since microorganisms are competent in degrading petroleum hydrocarbons (Sangeetha and Thangadurai 2014). Bioremediation of crude oil contaminated soil can be enhanced by stimulation of the indigenous microorganism, provision of nutrients and oxygen into the soil (biostimulation) (Seklemova et al. 2001) and through inoculation of an enhanced microbial consortium into the soil (bioaugmentation) (Richard and Vogel 1999). Abattoir wastewater contains high levels of microorganisms, such as fungi and bacteria that are capable of degrading petroleum hydrocarbons (Ogbonna et al. 2012; Umanu and Owoseni 2013). The aim of this study was to determine the effect of abattoir wastewater on cowpea seedlings grown in crude oil contaminated soil, in a bid to establish the possible use of abattoir wastewater as a bio-resource in crude oil contaminated farm lands.

\section{Materials and methods}

\section{Materials}

The reagents used were high-quality analytical grades. The Vigna unguiculata (L) (IT845-2246-4 accession) seeds, experimental soil and crude oil were obtained as reported in Achuba (2006). Abattoir wastewater was obtained from local slaughterhouses in Obiaruku, Delta State, Nigeria. It was collected from four different sites and pooled together. The wastewater was filtered to remove solid materials as well as suspended animal fats and oil. The temperature was determined with mercury thermometer while the $\mathrm{pH}$ was measured with pH meter (Model, Jenway 3020). Conductivity meter (C0150) was used to determine total dissolved solid and conductivity. Portable turbidity meter (Lamotte 2020) was used to determine turbidity. Dissolved oxygen meter (model Acorn DO) was used to determine biochemical oxygen demand (BOD).Closed reflux method was used to determine chemical oxygen demand (COD). Total suspended solid (TSS) was determined as earlier described (Anon 1992).The physicochemical properties of the wastewater are shown in Table 1:

\section{Study location}

The study was carried out in the research laboratory of the Department of Biochemistry, Delta State University, Abraka,
Nigeria. It is located between latitude $5^{\circ} 45^{\prime}$ and $5^{\circ} 50^{\prime} \mathrm{N}$ and longitude $6^{\circ}$ and $6^{\circ} 15^{\prime} \mathrm{E}$. It is in the rainforest region with annual rainfall of $3000 \mathrm{~mm}$ and temperature of between $28{ }^{\circ} \mathrm{C}$ and $33{ }^{\circ} \mathrm{C}$ (UNDP (2006). The topography is lowland plain about above $45 \mathrm{~m}$ sea level. The soil type is made up of ferrosal red and brown soil with abundant free iron oxide (Osakwe 2012).

\section{Preliminary assessment of abattoir wastewater}

A preliminary study was undertaken to determine the exact volume of abattoir wastewater that would be suitable for the amelioration of the toxic effects of crude oil treatments. Plant growth parameters (data not shown) and metabolic status of cowpea seedlings exposed to $40 \mathrm{ml}$ of abattoir wastewater treatment of soil was found to perform better compared to other levels of treatments $(10,20,30,50,60$, 80 and $100 \mathrm{ml}$ ) (Achuba and Ekute 2017).

\section{Experimental design}

One hundred planting bags (volume and height $1178.3 \mathrm{~cm}^{3}$ $15 \mathrm{~cm})$ filled soil $(1.6 \mathrm{~kg})$ were used for this study. The experiment was divided into two series. In series $\mathrm{A}$, each bag (Groups 1-6) was treated with $0.10,0.25,0.50,1.00$, $1.50,2.00$ and $0.00 \%(\mathrm{v} / \mathrm{w})$ of whole crude oil. Each treatment was replicated five times. Series B had same groups 1-6 treatments of crude oil in addition to treatment with abattoir wastewater $(40 \mathrm{ml}$ each) and each treatment replicated five times as well. Five seeds of the $V$. unguiculata were planted in each test bag. During the experiment, the setup was watered $\left(80 \mathrm{~cm}^{3}\right)$ daily to keep the soil moist. Record of germination was taken every 4 days until the 12th day and seeds which did not germinate were regarded as not germinable.

\section{Determination of total sugar content, amino acid and total protein}

The homogenate used for the determination of total sugar, amino acid and protein was prepared as reported by Achuba (2006) The sugar was determined as described by Tietz (1982), while total free amino acid was determined by ninhydrin after deproteination with 5\% trichloroacetic acid (TCA). The amount of total protein was determined according to Lowry et al. (1951).

Table 1 Physicochemical properties of abattoir wastewater used

\begin{tabular}{|c|c|c|c|c|c|c|c|c|}
\hline Appearance & $\operatorname{Temp}\left({ }^{\circ} \mathrm{C}\right)$ & $\mathrm{pH}$ & Conductivity $\left(\mathrm{dS} \mathrm{m}{ }^{-1}\right)$ & Turbidity (NTU) & $\operatorname{TDS}\left(\mathrm{mg} \mathrm{L}^{-1}\right)$ & TSS $\left(\mathrm{mg} \mathrm{L}^{-1}\right)$ & BOD $\left(\mathrm{mg} \mathrm{L}^{-1}\right)$ & $\operatorname{COD}\left(\mathrm{mg} \mathrm{L}^{1}\right)$ \\
\hline Turbid & $29 \pm 2$ & $5.6 \pm 0.3$ & $35.0 \pm 1$ & $8.3 \pm 0.1$ & $740 \pm 11.7$ & $884 \pm 3.0$ & $48 \pm 2.3$ & $150 \pm 10.1$ \\
\hline
\end{tabular}

Temp temperature, TDS total dissolved solid, TSS total suspended solid, BOD biological oxygen demand, COD chemical oxygen demand 


\section{Determination of photosynthetic pigments (chlorophyll and total carotene)}

The leaves $(1.0 \mathrm{~g})$ were homogenized using a mortar and pestle in $96 \%$ methanol and the homogenate obtained was centrifuged at $2500 \mathrm{rpm}$ for $10 \mathrm{~min}$. The supernatant obtained diluted. The concentration of total chlorophyll was determined as described by Lichtenthaler (1987). To estimate the concentrations of carotenoid and chlorophyll, the absorbance of the supernatant was read at 662, 646 and $470 \mathrm{~nm}$. The concentrations of these molecules were estimated by the formula of Duxbury and Yentsch (1956).

\section{Assay for alpha-amylase activity and determination of starch phophorylase activity in the cotyledons of cowpea seedlings}

The alpha-amylase assay was carried out by the method of Gupta et al. (2003) using the supernatant obtained from the homogenization and centrifugation of the pooled cotyledons $(0.5 \mathrm{~g}$, kept in ice). The activity was calculated using the formula proposed by Xiao et al. (2006). The method of Singh and Steinnes (1976) was adopted for the determination of starch phosphorylase activity.

\section{Preparation of homogenate for the determination of oxidative stress makers}

The cowpea leaves $(0.05 \mathrm{~g}), 0.05 \mathrm{M}$ phosphate buffer $\mathrm{pH} 7.5$ and few drops of butylated hydroxyl toluene (BHT), were homogenized in mortar (that was previously chilled at $4{ }^{\circ} \mathrm{C}$ ) with pestle. The mixture was filtered with cheese cloth and the filtrate centrifuged at $5000 \mathrm{~g}$ for $10 \mathrm{~min}$.

\section{Determination of oxidative stress markers}

Lipid peroxidation was determined according to the method of Gutteridge and Wilkins (1982).The activity of total superoxide dismutase was determined as described by Misra and Fredorich (1972), while MnSOD and Cu/ZnSOD were determined as reported by Crapo et al. (1978). The activities of catalase and xanthine oxidase were determined as reported by Rani et al. (2004) and were expressed as units/g wet tissue.

\section{Statistical analysis}

The results were analyzed using one way analysis of variance (ANOVA) and post Hoc Fisher's test for multiple comparison with the aid of statistical package for social science (SPSS), version 20. Level of significance was set at $p$ values $<0.05$.

\section{Results}

The effect of adding abattoir wastewater (AWW) to crude oil treated soil on the concentrations of sugar, protein, amino acid and $\beta$-carotene in the leaves of cowpea seedlings planted in crude oil polluted soil is shown in Table 2. The increase in the concentration of total sugar of the seedlings was significant $(p<0.05)$ at all the levels of contaminations

Table 2 Effect of abattoir wastewater treatment on the level of sugar, protein, amino acid and $\beta$-carotene in cowpea seedlings exposed to crude oil treated soil

\begin{tabular}{|c|c|c|c|c|c|c|c|c|}
\hline \multirow{2}{*}{$\begin{array}{l}\text { Concen- } \\
\text { tration } \\
\text { of crude } \\
\text { in soil } \\
(\% \mathrm{v} / \mathrm{w} \\
\left.\mathrm{ml} \mathrm{g}^{-1}\right)\end{array}$} & \multicolumn{2}{|c|}{ Total sugar $\left(\mathrm{mg} \mathrm{g}^{-1}\right)$} & \multicolumn{2}{|c|}{ Total protein $\left(\mathrm{mg} \mathrm{g}^{-1}\right)$} & \multicolumn{2}{|c|}{ Total amino acid $\left(\mathrm{mg} \mathrm{g}^{-1}\right)$} & \multicolumn{2}{|c|}{$\beta$-carotene $\left(\mathrm{mg} \mathrm{g}^{-1}\right)$} \\
\hline & Crude & Crude + AWW & Crude & Crude + AWW & Crude & Crude + AWW & Crude & Crude + AWW \\
\hline 0.00 & $33.27 \pm 0.86$ & $32.40 \pm 0.27$ & $19.60 \pm 0.20$ & $20.73 \pm 0.78$ & $3.77 \pm 0.15$ & $3.40 \pm 0.20$ & $22.57 \pm 0.87$ & $25.00 \pm 1.31$ \\
\hline 0.10 & $41.20 \pm 0.78^{\mathrm{a}}$ & $38.53 \pm 2.29^{\mathrm{a}}$ & $18.77 \pm 0.15$ & $19.00 \pm 0.36$ & $3.67 \pm 0.06$ & $3.70 \pm 0.01^{\mathrm{a}}$ & $18.87 \pm 1.43$ & $21.27 \pm 0.91^{\mathrm{d}}$ \\
\hline 0.25 & $43.57 \pm 0.75^{\mathrm{a}}$ & $42.23 \pm 5.13^{\mathrm{a}}$ & $19.87 \pm 0.25$ & $19.23 \pm 0.15$ & $3.83 \pm 0.06$ & $3.75 \pm 0.06^{\mathrm{a}}$ & $16.37 \pm 0.67$ & $20.23 \pm 0.75^{\mathrm{d}}$ \\
\hline 0.50 & $47.63 \pm 0.67^{\mathrm{a}}$ & $45.60 \pm 0.20^{\mathrm{a}}$ & $20.70 \pm 0.10$ & $19.83 \pm 0.25$ & $3.93 \pm 0.06$ & $3.80 \pm 0.07^{\mathrm{a}}$ & $17.48 \pm 1.18$ & $20.90 \pm 0.96^{\mathrm{d}}$ \\
\hline 1.00 & $56.40 \pm 0.44^{\mathrm{a}}$ & $46.07 \pm 0.15^{\mathrm{ab}}$ & $21.57 \pm 0.45^{\mathrm{a}}$ & $23.40 \pm 0.66^{\mathrm{a}}$ & $4.13 \pm 0.06^{\mathrm{a}}$ & $4.13 \pm 0.02^{\mathrm{a}}$ & $13.33 \pm 0.75$ & $18.10 \pm 0.82^{\mathrm{d}}$ \\
\hline 1.50 & $57.57 \pm 0.76^{\mathrm{a}}$ & $46.93 \pm 0.71^{\mathrm{ab}}$ & $24.50 \pm 0.47^{\mathrm{a}}$ & $22.70 \pm 0.20^{\mathrm{ab}}$ & $4.50 \pm 0.10^{\mathrm{a}}$ & $4.10 \pm 0.05^{\mathrm{a}}$ & $12.43 \pm 0.49$ & $17.53 \pm 1.16^{\mathrm{d}}$ \\
\hline 2.00 & $59.30 \pm 0.76^{\mathrm{a}}$ & $49.43 \pm 0.71^{\mathrm{ab}}$ & $26.43 \pm 0.47^{\mathrm{a}}$ & $23.60 \pm 0.20^{\mathrm{ab}}$ & $4.80 \pm 0.10^{\mathrm{a}}$ & $4.25 \pm 0.05^{\mathrm{ab}}$ & $12.43 \pm 0.49$ & $17.53 \pm 1.16^{\mathrm{d}}$ \\
\hline
\end{tabular}

Results are expressed as mean \pm SD of three determinations

${ }^{a}$ Significantly higher than control

${ }^{\mathrm{b}}$ Significantly lower than crude oil alone treatment

${ }^{\mathrm{c}}$ Significantly lower than the control

${ }^{\mathrm{d}}$ Significantly higher than crude oil alone treatment 
of soil with crude oil. However, the increase became significant at $1.00 \%$ concentration of crude oil treatment of soil for both total protein and total amino acid. On the other hand, a significant decrease $(p<0.05)$ in concentration of $\beta$-carotene in the leaves of cowpea seedlings planted in crude oil treated soil relative to the control values was noted. Treatment of the crude oil contaminated soil with AWW resulted in decrease in total sugar, total protein and total amino acid compared with those in crude oil alone groups. The decrease was significant at higher concentrations of crude oil in soil (1.00, 1.50 and $2.00 \%)$. Moreover, treatment of the crude oil contaminated soil with AWW significantly increased the $\beta$-carotene content of the cowpea seedlings except at $0.10 \%$ concentration of crude oil in soil.

Crude oil treatment of soil decreased the amount of chlorophyll in the leaves of cowpea seedlings compared to the control (Table 3). The decrease was significant $(p<0.05)$ for chlorophyll except at lower concentrations of crude oil in soil. However, seedlings exposed to AWW had significantly higher chlorophyll content at higher levels of soil contamination. Similarly, crude oil contaminated soil decreased the activities of $\alpha$-amylase and starch phosphorylase in the cotyledon of cowpea seedlings. Treatment of crude oil contaminated soil with AWW resulted in increase in the activities of starch metabolizing enzymes studied. However, the increase was not significant for starch phosphorylase and was only significant for $\alpha$-amylase at $2.00 \%$ concentration of crude oil.

Lipid peroxidation significantly increased in the leaves of cowpea seedlings as the concentration of crude oil in soil increased (Table 4). The addition of AWW to the crude oil treated soil significantly decreased lipid peroxidation in the leaves of the cowpea seedlings as compared to the corresponding crude oil alone treatment. The activity of xanthine oxidase increased significantly at low levels of soil treatment with crude oil $(0.10$ and $0.25 \%)$. However, the activity of the enzyme decreased at higher level of crude oil in soil $(0.50,1.00$ and $2.00 \%)$. Treatment with AWW caused significant increase in the activity of xanthine oxidase as compared with the corresponding crude oil alone treatment. Table 3 also indicates that planting cowpea seedlings in crude oil contaminated soil decreased the activities of catalase and aldehyde oxidase and the decrease was significant at all contamination levels for catalase while it was only significant at $2.00 \%$ level soil contamination for aldehyde oxidase. Treatment with AWW increased catalase activity significantly $(p<0.05)$ compared to the corresponding crude oil alone treatment while it was only significant at 1.50 and $2.00 \%$ level of contamination for aldehyde oxidase.

Table 5 shows that contamination of soil with crude oil significantly $(P<0.05)$ increased total superoxide dismutase (SOD) at low levels of soil contamination with crude oil $(0.10,0.25$ and $0.50 \%)$ but significantly decreased total SOD at higher levels of crude oil treatment of soil (1.00, 1.50 and $2.00 \%)$. While contamination with crude oil significantly increased CuZnSOD activity at all levels of soil contamination, but decreased MnSOD activity, although not significant relative to control value. Treatment of contaminated soil with AWW significantly decreased total SOD at lower concentrations of crude oil in soil $(0.10,0.25$ and $0.50 \%)$ contamination levels but significantly increased total SOD at higher level of soil contamination (1.00, 1.50 and 2.00\%). Moreover, treatment with AWW decreased CuZnSOD activity significantly at higher levels of soil contamination while MnSOD activity was not significantly increased.

Table 3 Effect of abattoir wastewater on the content of chlorophyll, $\alpha$-amylase and starch phosphorylase in cowpea seedlings exposed to crude oil polluted soil

\begin{tabular}{|c|c|c|c|c|c|c|}
\hline \multirow[t]{2}{*}{$\begin{array}{l}\text { Concentration of crude oil } \\
\text { in soil }\left(\% \mathrm{v} / \mathrm{w} \mathrm{ml} \mathrm{g}^{-1}\right)\end{array}$} & \multicolumn{2}{|c|}{ Total chlorophyll $\left(\mathrm{mg} \mathrm{g}^{-1}\right)$} & \multicolumn{2}{|c|}{$\alpha$-amylase activity (Unit $\mathrm{ml}^{-1}$ ) } & \multicolumn{2}{|c|}{$\begin{array}{l}\text { Starch phosphorylase activity } \\
\left(\mathrm{mg} \mathrm{min}^{-1} \mathrm{gfw}\right)\end{array}$} \\
\hline & Crude & Crude + AWW & Crude & Crude + AWW & Crude & Crude + AWW \\
\hline 0.00 & $288.33 \pm 2.08$ & $303.00 \pm 1.00$ & $20.87 \pm 1.44$ & $24.83 \pm 1.43$ & $1.07 \pm 0.05$ & $1.17 \pm 0.04$ \\
\hline 0.10 & $280.33 \pm 3.06$ & $290.33 \pm 2.52^{\mathrm{d}}$ & $18.63 \pm 0.45$ & $21.07 \pm 1.60$ & $1.02 \pm 0.09$ & $1.03 \pm 0.03$ \\
\hline 0.25 & $277.33 \pm 4.73$ & $291.67 \pm 1.53^{\mathrm{d}}$ & $18.13 \pm 0.15$ & $19.50 \pm 0.66$ & $0.93 \pm 0.07$ & $1.04 \pm 0.06^{\mathrm{d}}$ \\
\hline 0.50 & $238.67 \pm 7.09^{\mathrm{a}}$ & $289.00 \pm 1.00^{\mathrm{bd}}$ & $19.17 \pm 1.37$ & $20.00 \pm 1.59$ & $1.18 \pm 0.28$ & $1.26 \pm 0.09^{\mathrm{d}}$ \\
\hline 1.00 & $215.67 \pm 0.57^{\mathrm{a}}$ & $258.00 \pm 7.00^{\mathrm{abd}}$ & $17.67 \pm 1.12$ & $19.13 \pm 0.8^{\mathrm{d}}$ & $0.83 \pm 0.09$ & $0.99 \pm 0.05^{\mathrm{d}}$ \\
\hline 1.50 & $211.67 \pm 2.08^{\mathrm{a}}$ & $236.00 \pm 9.54^{\mathrm{abd}}$ & $15.40 \pm 0.96^{\mathrm{a}}$ & $18.50 \pm 0.75^{\mathrm{d}}$ & $0.68 \pm 0.05^{\mathrm{a}}$ & $0.93 \pm 0.09^{\mathrm{d}}$ \\
\hline 2.00 & $208.33 \pm 2.08^{\mathrm{a}}$ & $217.00 \pm 9.54^{\mathrm{d}}$ & $13.23 \pm 1.04^{\mathrm{a}}$ & $17.20 \pm 0.90^{\mathrm{abd}}$ & $0.52 \pm 0.04^{\mathrm{a}}$ & $0.79 \pm 0.06^{\mathrm{d}}$ \\
\hline
\end{tabular}

Results are expressed as mean \pm SD of three determinations

${ }^{\text {a }}$ Significantly higher than control

${ }^{\mathrm{b}}$ Significantly lower than crude oil alone treatment

${ }^{\mathrm{c}}$ Significantly lower than the control

${ }^{\mathrm{d}}$ Significantly higher than crude oil alone treatment 
Table 4 Effect of abattoir wastewater treatment on lipid peroxidation and activities of xanthine oxidase, catalase and aldehyde oxidase in cowpea seedlings exposed to crude oil treated soil

\begin{tabular}{|c|c|c|c|c|c|c|c|c|}
\hline \multirow{2}{*}{$\begin{array}{l}\text { Concentration of } \\
\text { crude oil in soil } \\
\left(\% \mathrm{v} / \mathrm{w} \mathrm{ml} \mathrm{g}^{-1}\right)\end{array}$} & \multicolumn{2}{|c|}{$\begin{array}{l}\text { Lipid peroxidation ( } \mathrm{nMol} \\
\mathrm{cm}^{-3} \text { ) }\end{array}$} & \multicolumn{2}{|c|}{$\begin{array}{l}\text { Xanthine oxidase } \\
\text { activity(Unit } \mathrm{cm}^{-3} \text { ) }\end{array}$} & \multicolumn{2}{|c|}{$\begin{array}{l}\text { Catalase activity (nmol } \mathrm{min}^{-1} \\
\text { gfw) }\end{array}$} & \multicolumn{2}{|c|}{$\begin{array}{l}\text { Aldehyde oxidase activity } \\
\left(\text { Unit } \mathrm{cm}^{-3} \text { ) }\right.\end{array}$} \\
\hline & Crude & Crude + AWW & Crude & Crude + AWW & Crude & Crude + AWW & Crude & Crude + AWW \\
\hline 0.00 & $0.98 \pm 0.12$ & $0.92 \pm 0.07$ & $3.78 \pm 0.57$ & $4.65 \pm 0.15$ & $1.08 \pm 0.13$ & $1.15 \pm 0.04$ & $1.29 \pm 0.17$ & $1.66 \pm 0.065$ \\
\hline 0.10 & $1.40 \pm 0.1^{\mathrm{a}}$ & $1.08 \pm 0.13^{b}$ & $4.47 \pm 0.44^{\mathrm{a}}$ & $4.71 \pm 0.26^{\mathrm{a}}$ & $0.83 \pm 0.11^{\mathrm{c}}$ & $1.25 \pm 0.08^{\mathrm{d}}$ & $1.23 \pm 0.08$ & $1.53 \pm 0.08^{\mathrm{d}}$ \\
\hline 0.25 & $1.74 \pm 0.0^{\mathrm{a}}$ & $1.32 \pm 0.11^{\mathrm{ab}}$ & $4.74 \pm 0.09^{\mathrm{a}}$ & $4.74 \pm 0.09^{\mathrm{a}}$ & $0.66 \pm 0.05^{\mathrm{c}}$ & $1.16 \pm 0.01^{\mathrm{d}}$ & $1.23 \pm 0.07$ & $1.48 \pm 0.06^{\mathrm{d}}$ \\
\hline 0.50 & $1.93 \pm 0.0^{\mathrm{a}}$ & $1.36 \pm 0.04^{\mathrm{ab}}$ & $3.98 \pm 0.09$ & $4.74 \pm 0.09^{\mathrm{ad}}$ & $0.94 \pm 0.06$ & $1.14 \pm 0.01^{\mathrm{d}}$ & $1.34 \pm 0.02$ & $1.58 \pm 0.03^{\mathrm{d}}$ \\
\hline 1.00 & $2.09 \pm 0.1^{\mathrm{a}}$ & $1.41 \pm 0.05^{\mathrm{ab}}$ & $3.18 \pm 0.04$ & $4.45 \pm 0.05^{\mathrm{ad}}$ & $0.71 \pm 0.04^{\mathrm{c}}$ & $1.01 \pm 0.09^{\mathrm{d}}$ & $1.40 \pm 0.40$ & $1.39 \pm 0.02$ \\
\hline 1.50 & $2.23 \pm 0.2^{\mathrm{a}}$ & $1.44 \pm 0.01^{\mathrm{ab}}$ & $3.11 \pm 0.09$ & $4.26 \pm 0.08^{\mathrm{d}}$ & $0.61 \pm 0.02^{\mathrm{c}}$ & $0.91 \pm 0.04^{\mathrm{d}}$ & $0.95 \pm 0.05$ & $1.18 \pm 0.07^{\mathrm{d}}$ \\
\hline 2.00 & $2.54 \pm 0.0^{\mathrm{a}}$ & $1.46 \pm 0.02^{\mathrm{ab}}$ & $3.10 \pm 0.12^{\mathrm{a}}$ & $4.15 \pm 0.16^{\mathrm{d}}$ & $0.53 \pm 0.05^{\mathrm{c}}$ & $0.85 \pm 0.11^{\mathrm{d}}$ & $0.72 \pm 0.053$ & $1.33 \pm 0.41^{\mathrm{d}}$ \\
\hline
\end{tabular}

Results are expressed as mean $\pm \mathrm{SD}$ of three determinations

${ }^{\text {a }}$ Significantly higher than control

${ }^{\mathrm{b}}$ Significantly lower than crude oil alone treatment

${ }^{\mathrm{c}}$ Significantly lower than the control

${ }^{\mathrm{d}}$ Significantly higher than crude oil alone treatment

Table 5 Effect of abattoir wastewater on superoxide dismutase activities cowpea seedlings planted in crude oil treated soil

\begin{tabular}{|c|c|c|c|c|c|c|}
\hline \multirow{2}{*}{$\begin{array}{l}\text { Concentration of crude oil } \\
\text { in soil }\left(\% \mathrm{v} / \mathrm{w} \mathrm{ml} \mathrm{g}^{-1}\right)\end{array}$} & \multicolumn{2}{|c|}{ Total SOD (Unit $\left.\mathrm{g}^{-1} \mathrm{fw}\right)$} & \multicolumn{2}{|c|}{ CuZnSOD (Unit $\left.\mathrm{g}^{-1} \mathrm{fw}\right)$} & \multicolumn{2}{|c|}{ MnSOD (Unit $\left.\mathrm{g}^{-1} \mathrm{fw}\right)$} \\
\hline & Crude & Crude + AWW & Crude & Crude + AWW & Crude & Crude + AWW \\
\hline 0.00 & $2.28 \pm 0.15$ & $2.21 \pm 0.17$ & $2.10 \pm 0.09$ & $2.06 \pm 0.02$ & $0.97 \pm 0.13$ & $0.84 \pm 0.11$ \\
\hline 0.10 & $2.73 \pm 0.13^{\mathrm{a}}$ & $2.37 \pm 0.06$ & $2.23 \pm 0.07$ & $2.09 \pm 0.08$ & $0.44 \pm 0.51$ & $0.37 \pm 0.43$ \\
\hline 0.25 & $3.01 \pm 0.09^{\mathrm{a}}$ & $2.54 \pm 0.37^{\mathrm{c}}$ & $2.37 \pm 0.04^{\mathrm{a}}$ & $2.25 \pm 0.06$ & $0.74 \pm 0.48$ & $0.84 \pm 0.57$ \\
\hline 0.50 & $3.18 \pm 0.17^{\mathrm{a}}$ & $2.64 \pm 0.05^{\mathrm{c}}$ & $2.45 \pm 0.07^{\mathrm{a}}$ & $2.13 \pm 0.12^{\mathrm{c}}$ & $0.48 \pm 0.21$ & $0.81 \pm 0.11^{\mathrm{d}}$ \\
\hline 1.00 & $1.96 \pm 0.07$ & $2.69 \pm 0.09^{\mathrm{ad}}$ & $2.44 \pm 0.07^{\mathrm{a}}$ & $2.28 \pm 0.07$ & $0.73 \pm 0.08$ & $0.82 \pm 0.01^{\mathrm{d}}$ \\
\hline 1.50 & $1.73 \pm 0.12^{\mathrm{b}}$ & $2.46 \pm 0.07^{\mathrm{d}}$ & $2.34 \pm 0.08^{\mathrm{a}}$ & $2.07 \pm 0.03^{c}$ & $0.63 \pm 0.06$ & $0.75 \pm 0.11^{\mathrm{d}}$ \\
\hline 2.00 & $1.45 \pm 0.10^{\mathrm{b}}$ & $2.62 \pm 0.29^{\mathrm{d}}$ & $2.49 \pm 0.11^{\mathrm{a}}$ & $2.20 \pm 0.11^{\mathrm{c}}$ & $0.47 \pm 0.05$ & $0.64 \pm 0.09^{d}$ \\
\hline
\end{tabular}

Results are expressed as mean \pm SD of three determinations

${ }^{a}$ Significantly higher than control

${ }^{\mathrm{b}}$ Significantly lower than crude oil alone treatment

${ }^{\mathrm{c}}$ Significantly lower than the control

${ }^{\mathrm{d}}$ Significantly higher than crude oil alone treatment

\section{Discussion}

Adverse alterations in biochemical parameters have been reported as indices of crude oil and its refined products mediated stress in plants (Achuba 2006; Peretiemo-Clarke and Achuba 2007; Bona et al. 2011; Al-Hawas et al. 2012). The present study showed increases in total sugar, total protein and total amino acid contents of the cowpea seedlings planted in crude oil treated soil relative to the control (Table 2). This increase in these macromolecules indicates metabolic stress (Achuba 2006) and the result correlates with earlier reports of Peretiemo-Clarke and Achuba (2007) and Al-Hawas et al. (2012) on the effect of hydrocarbon treated soil on the seedlings of peanut and
Jojoba, respectively. On the other hand, the $\beta$-carotene and chlorophyll contents of the cowpea seedlings decreased significantly except at low levels $(0.10-0.5 \%)$ of crude oil contamination of soil for chlorophyll (Tables 2 and 3). This correlates with the results of Achuba (2006) and AlHawas et al. (2012). While both researches found crude oil to cause significant decrease in chlorophyll content in the exposed plants, Al-Hawas et al. (2012) also reported significant decrease in carotenoids and total pigments of Jojoba seedlings with increasing concentration of crude oil. However, treatment with abattoir wastewater (AWW) significantly $(p<0.05)$ increased the $\beta$-carotene content at all contamination levels while the chlorophyll content was significantly increased at low levels $(0.10-0.5 \%)$ of contamination as compared to the corresponding crude 
oil alone groups. This correlates with the findings of other researchers who employed organic waste products to remediate the adverse effects of soil contamination by crude oil on plant growth and yield (Akujobi et al. 2011; Ekpo and Nya 2012).

Achuba (2006) reported inhibition of activities of $\alpha$-amylase and starch phosphorylase in the cotyledon of the cowpea seedlings planted in petroleum-treated soil. Treatment of crude oil contaminated soil with AWW enhanced the activities of the starch degrading enzymes, $\alpha$-amylase and starch phosphorylase (Table 3), although the increase was not significant for starch phosphorylase and was only significant for $\alpha$-amylase at higher (1.00-2.00\%) concentrations of crude oil in soil. Abattoir wastewater enhancement of $\alpha$-amylase and starch phosphorylase activities in cowpea seedling was reported recently (Achuba and Ekute 2017).

In this study, lipid peroxidation increased as the concentration of crude oil increased (Table 4). This agrees with the findings of Olubodun and Eriyamremu (2015). The increase may have stemmed from petroleum hydrocarbon-induced free radicals generation, with resultant oxidative stress and peroxidation of lipid (Ortega-Villasante 2005; Dietz 2010). Treatment of the crude oil contaminated soil with AWW significantly decreased lipid peroxidation in cowpea seedlings as compared to the corresponding seedlings in crude oil alone treatment.

The activity of xanthine oxidase increased significantly at lower $(0.10-0.50 \%)$ levels of contamination while it decreased, though not significantly at higher levels (1.00-2.00\%) of contamination. Treatment with AWW increased the activity of xanthine oxidase as compared with the corresponding crude oil alone treatment. Earlier report indicated that abattoir wastewater altered sulphite oxidase activity in hydrocarbon contaminated soil (Achuba and Okunbor 2015).

One of the consequences of environmental stress in plants is the imbalance in the generation and removal reactive oxygen species (Al-Hawas et al. 2012). However, living organisms such as plants possess a number of antioxidant enzymes like superoxide dismutase (SOD) and catalase that guide against oxidative damage (Asada 1994). The present study showed that exposure of cowpea seedlings to crude oil contaminated soil negatively altered the activities of catalase, aldehyde oxidase, total superoxide dismutase (SOD), $\mathrm{Cu} / \mathrm{ZnSOD}$ and MnSOD (Table 5). Al-Hawas et al. (2012) had reported the inhibition of catalase activity as well as increase in SOD activity in Jojoba (Simmodsia chinensis) seedling exposed to crude oil contamination levels. On the other hand, Olubodun and Eriyamremu (2015) reported a decreased level of SOD. The inconsistence levels of SOD at different levels of crude oil contamination observed in this present study agrees with previous reports that different levels of SOD activity might occur depending on the living organism involved and environmental conditions (Sgherri et al. 2000; Al-Hawas et al. 2012). Generally, treatment with AWW positively altered the activities of catalase, aldehyde oxidase and various superoxide dismutases. However, this is not concentration dependent. On the whole, these observations indicate that AWW has an ameliorative effect on crude oil mediated oxidative stress.

Abattoir wastewater contains organic substances, hydrocarbon-utilizing microorganisms and a relatively significant amount of plants nutrients (Neboh et al. 2013; Umanu and Owoseni 2013). Therefore, the observed improvement in the metabolic profile of cowpea seedlings in this study may be attributed to the organic matter, hydrocarbon-utilizing microorganisms and essential nutrients present in AWW. Umanu and Owoseni (2013) and Ogbonna (2014) reported that various bacteria strains capable of hydrocarbon degradation were isolated from soil and abattoir effluent and these include Pseudomonas aeruginosa, Bacillus spp, Alcaligenes faecalis, and serratia spp, while the fungi isolated were Aspergillus niger, Penicillium chrysogenum and Fusarium sp. The hydrocarbon-utilizing microorganisms may have enhanced the removal of the toxic hydrocarbons in the contaminated soil (Umanu and Owoseni 2013; Kumar et al. 2014) while the organic matter and essential nutrients may have replenished the soil nutrient status. The promotive effect of biofertilizer was previously reported (Al-Abdallah et al. 2017; Zarei et al. 2017).This may be the basis for enhanced soil fertility (Etuk et al. 2013) and improved metabolic status of cowpea seedlings exposed to AWW pretreated crude oil contaminated soil.

\section{Conclusion}

The present study emphasized that the abattoir wastewater is an effective bioremediation resource for crude oil contaminated soil and at the same instance remediated the adverse effects of crude oil exposed plants to crude oil polluted soil. Therefore, abattoir wastewater should be harnessed and used in treating crude oil polluted farmland so as to reduce its toxicity on crop plants.

Open Access This article is distributed under the terms of the Creative Commons Attribution 4.0 International License (http://creativecomm ons.org/licenses/by/4.0/), which permits unrestricted use, distribution, and reproduction in any medium, provided you give appropriate credit to the original author(s) and the source, provide a link to the Creative Commons license, and indicate if changes were made.

\section{References}

Achuba FI (2006) The effect of sublethal concentrations of crude oil on the growth and metabolism of Cowpea (Vigna unguiculata) 
seedlings. Environmentalist 26:17-20. https://doi.org/10.1007/ s10669-006-5354-2

Achuba FI (2014) Petroleum products in soil mediated oxidative stress in cowpea (Vigna ungiculata) and Maize (Zea mays) seedlings. Open J Soil Sci. 4:417-435. https://doi.org/10.4236/ojss.2014 .412042

Achuba FI, Ekute BO (2017) Effect of abattoir wastewater on the metabolic status of cowpea seedlings. In: Proceedings of the fourth Delta State University Faculty of Science International Conference. pp 98-103

Achuba FI, Okoh PN (2014) Effect of petroleum products on soil catalase and dehydrogenase activities. Open J. Soil Sci. 4:399406. https://doi.org/10.4236/ojss.2014.412040

Achuba FI, Okunbor G (2015) Abattoir waste water attenuates kerosene toxicity on cowpea (Vigna unguiculuta) seedlings. Biokemistri 27(4):159-162

Akujobi CO, Onyeagba RA, Nwaugo VO, Odu NN (2011) Effect of nutrient amendments of diesel oil polluted soil on plant growth parameters. Curr Res J Bio Sci. 3(4):421-429

Al-Abdallah NM, Basalah MO, Roushdy SS (2017) The promotive effect of algal biofertilizers on growth and some metabolic activities of Vigna unguiculata $\mathrm{L}$. under salt stress conditions Egypt. J Exp Biol 13(2):187-195. https://doi.org/10.5455/egyj ebb. 20170616083640

Al-Hawas GHS, Shukry WM, Azzoz MM, Al-Moaik RMS (2012) The effect of sublethal concentrations of crude oil on the metabolism of Jojoba (Simmodsia chinensis) seedlings. Int J Plant Sci 3(4):54-62

Anon R (1992) Standard methods of water and wastewater examination, 18th edn. American Public Health Association, Washington DC, pp 2-172

Asada K (1994) Production and action of active oxygen species in photosynthetic tissue. In: Foyer CH, Mullineaux PM (eds) Causes of photooxidative stress and amelioration of defense systems in plants. CRC Press, Boca Raton, pp 77-104

Bona C, de Rezende Gedir IM, Santos DO, de Souza LA (2011) Effect of soil contaminated by diesel oil on the germination of seeds and the growth of Schinus terebinthifolius Raddi (Anacardiaceae) seedlings. Braz Arch Bio. Technol. 54(6):63-69. http s://doi.org/10.1590/S1516-89132011000600025

Crapo JD, McCord JM, Fridovich I (1978) Preparation and assay of superoxide dismutase. Meth Enzymol 53:382-393

Dietz KJ (2010) Redox-dependent regulation, redox control and oxidative damage in plant cells subjected to abiotic stress. In: Sunkar R (ed) Plant stress tolerance: methods and protocols. Humana Press, London, pp 57-70

Duxbury AC, Yentsch CS (1956) Plankton pigment nomographs. J Marine Res 15:92-101

Ekpo FE, Nya EJ (2012) Effect of poultry manure amendments on diesel oil polluted soil on germination and growth performance of forest trees. J Res Environ Sci Toxicol 1(17):195-200

Etuk EA, Ogboi KC, Nwadinigwe CA (2013) Bioremediation of hydrocarbon polluted soil in the lowland forest ecosystem in the niger delta through enhanced natural attenuation process (ENAP). Int J Appl Sci Technol 3(8):129-137

Gupta RP, Gigras H, Mohapatra GV, Kumar A, Chauhan B (2003) Microbial amylases: a biotechnological perspective. Proc Biochem 38:1599-1616

Gutteridge JMC, Wilkins S (1982) Copper-dependent hydroxyl radical damage to ascorbic acid. FEBS Lett 137:327-329

Kumar V, Singh S, Manhas A, Singh J, Singla S, Kaur P, Data S, Negi P, Kalia A (2014) Bioremediation of petroleum hydrocarbon by using Pseudomonas species isolated from petroleum contaminated soil. Orient J Chem 30(4):1771-1776. https://doi. org/10.13005/ojc/300436
Lichtenthaler HK (1987) Chlorophylls and carotenoids: pigments of photosynthetic biomembranes. In: Packer L, Douce R (eds) Methods in enzymology. Academic Press, New York, pp 350-382

Lowry OH, Rosebrough NJ, Farr AL, Randal RJ (1951) Protein measurement with the folin phenol reagent. Biol Chem 193:265-275

Misra HP (1972) Fridovich I (1972) The role of superoxide ion in the antioxidation of epinephrine and a simple assay for superoxide dismutase. J Biol Chem 247:3170-3175

Neboh HA, Ilusanya OA, Ezekoye CC, Orji FA (2013) Assessment of Ijebu-Igbo Abattoir effluent and its impact on the ecology of the receiving soil and river. J Environ Sci Toxicol Food Technol 7(5):61-67. https://doi.org/10.9790/2402-0756167

Ogbonna DN (2014) Distribution of microorganisms in water, soils and sediment from abattoir wastes in southern Nigeria. Int J Curr Microbiol App Sci 3(9):1183-1200

Ogbonna DN, Ideriah TJK, Nwachukwu MI (2012) Biodegradation of polycyclic aromatic hydrocarbons by associated microbes from abattoir wastes in the Niger delta, Nigeria. J Microbiol Res 2(6):157-169. https://doi.org/10.5923/j.microbiology.20120206 .02

Olubodun SO, Eriyamremu GE (2015) Antioxidant enzymes and crude mitochondria ATPases in the radicle of germinating bean (Vigna unguiculata) exposed to different concentrations of crude oil. Int J Biol Food Vet Agric Eng 9(3):220-225

Ortega-Villasante C, Rellán-Álvarez R, del Campo FF, Carpena-Ruiz RO, Hernández LE (2005) Cellular damage induced by cadmium and mercury in Medicago sativa. J Expt Bot 56:2239-2251. http s://doi.org/10.1093/jxb/eri223

Osakwe SA (2012) Effect of cassava processing mill effluent on physical and chemical properties of soils in Abraka and Environs, Delta State, Nigeria. Chem Mat Res 2(7):27-39

Otitoju O, Udebuani AC, Ebulue MM, Onwurah IN (2017) Enzymebased assay for toxicological evaluation of soil ecosystem polluted with spent engine oil. Agric Ecol Res Int J 11(3):1-13. https://doi. org/10.9734/jaeri/2017/27605

Peretiemo-Clarke BO, Achuba FI (2007) Phytochemical effect of petroleum on peanut (Arachis hypogea) seedlings. Plant Pathol J 6:179-182. https://doi.org/10.3923/ppj.2007.179.182

Rani P, Meena UK, Karthikeyan J (2004) Evaluation of antioxidant properties of berries. India J Clin Biochem 19(2):103-110. http s://doi.org/10.1007/BF02894266

Richard JY, Vogel TM (1999) Characterization of a soil bacterial consortium capable of degrading diesel fuel. Int Biodet Biod 44:93100. https://doi.org/10.1016/s0964-8305(99)00062-1

Romantschuk M, Sarand I, Petanen T, Peltola R, Jonsson-Vihanne M, Koivula T, Yrjala K, Haahtela K (2000) Means to improve the effect of in situ bioremediation of contaminated soil: an over-view of novel approaches. Environ Pollut 107:179-185

Sangeetha J, Thangadurai D (2014) Effect of biologically treated petroleum sludge on seed germination and seedling growth of Vigna unguiculata (L.) Walp. (Fabaceae). Braz Arch Biol Technol 57(3):427-433. https://doi.org/10.1590/s1516-891320140050 00011

Seklemova E, Pavlvova A, Kovachenva K (2001) Biostimulation based bioremediation of diesel fuel: field domonstration. Biodegradation 12:311-316

Sgherri CL, Maffei M, Navari-Izzo F (2000) Antioxidative enzymes in wheat subjected to increasing water deficit and rewatering. J Plant Physiol 157:273-279. https://doi.org/10.1016/S0176-1617 (00)80048-6

Singh BB, Steinnes H (1976) Uptake of trace element by barley in Zinc polluted soil'. Soil Sci 121(1):38-43

Sivaraj R, Kumar KS, Radhakrishna A (2014) An investigation of growth and yield of Helianthus annus on diesel contaminated 
soil and bioremediated diesel contaminated soil. World J Pharm Res 3(10):1530-1544

Tietz NW (1982) Fundamentals of clinical chemistry. 2nd (ed) W.B. Saunder Co., New York, pp: 994-995

Umanu G, Owoseni RA (2013) Effects of abattoir effluent on microbial degradation of diesel oil in tropical agricultural soil. Pac J Sci Technol 14(1):604-612

UNDP (2006). Niger delta human development report. Pp 229

Wyszkowski M, Wyszkowska J (2005) Effect of enzymatic activity of diesel oil contaminated soil on the chemical composition of oat (Avena sativa L.) and maize (Zea mays L.). Plant Soil Environ 51(8):360-367

Wyszkowski M, Ziolkowska A (2008) Effect of petrol and diesel oil on content of organic carbon and mineral components in soil. Am Eur J Sust Agric 2(1):54-60

Wyszkowski M, Wyszkowska J, Ziółkowska A (2004) Effect of soil contamination with diesel oil on yellow lupine yield and macroelements content. Plant Soil Environ 50:218-226
Xiao Z, Storms R, Tsang A (2006) A quantitative starch-iodine method for measuring alpha-amylase and glucoamylase activities. Analyt Biochem 351(1):146-148. https://doi.org/10.1016/j.ab.2006 .01 .036

Zarei M, Abadi VAJM, Moridi A (2017) Comparison of vermiwash and vermicompost tea properties produced from different organic beds under greenhouse conditions. Int J Recycl Org Waste Agric. https://doi.org/10.1007/s40093-017-0186-2

Publisher's Note Springer Nature remains neutral with regard to urisdictional claims in published maps and institutional affiliations. 